\title{
KUALITAS FISIK DAN PALATABILITAS SILASE BATANG PISANG (MUSA PARADISIACA) SEBAGAI PAKAN TERNAK DOMBA EKOR GEMUK
}

\author{
Somad Qoiyum ${ }^{1}$, Ratna Kumala Dewi ${ }^{2}$, Dyanovita Al - Kurnia ${ }^{3}$ \\ Program Studi Fakultas Peternakan Universitas Islam Lamongan \\ 2 dan 3 Dosen Fakultas Peternakan - Universitas Islam Lamongan \\ Jl. Veteran No 53 A Lamongan \\ E-mail: somadqoiyum25@gmail.com
}

\begin{abstract}
Abstrak
Penelitian ini dilaksanakan pada bulan April sampai Mei tahun 2018 berlokasi di Desa Pangkaterjo Dusun Tuyuh Kecamatan Lamongan Kabupaten Lamongan. Tujuan dari prenelitian ini adalah untuk mengetahui pengaruh kualitas fisik dan palatabilitas presentasi pemberian pakan silase batang pisang (Musa paradisiaca) sebagai pakan ternak domba ekor gemuk. Kegunaan dari penelitian ini diharapkan agar digunakan sebagai bahan informasi dan bahan alternatif tentang pemanfaatan limbah pertanian berupa batang pisang. Materi yang digunakan dalam penelitian ini adalah 8 ekor domba ekor gemuk, batang pisang, dedak padi, pollard, garam, EM4, mollases dan air. Variabel yang di amati kualitas fisik silase batang pisang yang meliputi (tekstur, warna, aroma dan $\mathrm{pH}$ ) dan palatabilitas pakan per hari dan per minggu. Data yang dihasilkan dari penelitian dianalisis dengan mengunkan analisis statistik RAK (Rancangan Acak Kelompok). Hasil penelitian yang dapat disimpulkanbahwa pengaruh kualitas fisik silase batang pisang sangat baik, sedangkan pengaruh palatabilitas pada ternak domba ekor gemuk tidak berbeda nyata memberikan ( $T_{\text {hitung }}$ $\leq 0,05)$ berbeda nyata dengan $\left(T_{\text {hitung }} \leq 0,01\right)$, namun untuk penegelompokan yang berdasarkan jenis kelamin menunjukan yang sangat nyata.
\end{abstract}

Kata Kunci : Batang pisang (Musa paradisiaca), silase, palatabilitas

\section{PENDAHULUAN}

Pengaruh musim sangat menentukan ketersediaan hiajauan sebagai pakan. Pada musim penghujan produksi hijauan berlimpah dan sebaliknya di musim kemarau hijauan sebagai sumber pakan menjadi berkurang. Untuk mengatasi hal tersebut petani peternak memberi pakan dari sisa sisa limbah pertanian.

Pemanfaatan limbah sebagai pakan merupakan suatu alternatif dalam memenuhi kebutuhan nutrisi ternak ruminansia, selain dapat membantu mengurangi pencemaran lingkungan dan memberikan nilai ekonomis terhadap limbah yang belum termanfaatkan secara optimal.

Bahan pakan limbah pertanian merupakan salah satu alternatif yang dapat mendukung penyediaan pakan. Limbah yang digunakan diharapkan tidak bersaing dengan manusia salah satu adalah limbah batang pisang (Musa paradisiaca). Limbah batang pisang memenuhi aspek kuantitas, kontinuitas tetapi perlu adanya pengolahan pakan untuk meningkatkan kualitas batang pisang sebagai pakan. Dengan adanya penerapan teknologi yang dikenal silase, limbah yang mencemari lingkungan dapat diolah menjadi pakan yang berkualitas.

Kabupaten Lamongan merupakan wilayah kaya akan produksi hortikultura yang melimpah. Kabupaten Lamongan memiliki jumlah tanaman pisang yang menghasilkan 1.867 pohon dan dapat memproduksi pertahun sebesar 2.520,30 ton. (profil dan potensi Kabupaten Lamongan, 2017).

Kandungan batang pisang adalah sebagai berikut bahan kering $8,62 \%$, abu $24,31 \%$, lemak kasar $2,75 \%$, bahan ekstrak tanpa nitrogen $40,61 \%$, hemilosa $20,34 \%$, selulosa $26,64 \%$ dan lignin 9,92\% (Hasrida, 2011). Nilai nutrisi yang rendah dan penyimpanan yang tidak dapat 
bertahan lama pada limbah batang pisang menjadi faktor pembatas dalam penyediaan pakan oleh peternak. Solusi yang dapat diterapkan untuk meningkatkan kualitas limbah batang pisang (Musa paradisiaca) yaitu perapan salah satu teknologi silase yang dapat diterapkann pada limbah batang pisang. Oleh karena itu peneliti ingin mengetahui kualitas fisik dan palatabilitas silase batang pisang sebagi pakan ternak domba ekor gemuk.

\section{MATERI DAN METODE}

\section{Materi penelitian}

Penelitian ini dilakukan di laboraturium Universitas Islam Lamongan untuk uji kualitas fisik sedangkan uji palatabilitas silase batang pisang dilakukan di kandang peternak bapak hariono di desa karang langit kecamatan lamongan kabupaten lamongan. Bahan yang digunakan adalah batang pisang, dedak, polllard, garam, air, mollases, em4 dan ternak domba dengan metode eksperimen 4 perlakuan mengunkan rancangan acak kelompok (RAK). Apabila perlakuan berpengaruh nyata maka akan dilanjutkan deng uji duncan. Untuk mengetahui perlakuan mana yang terbaik.

Perlakuan yang diberikan adalah sebagai berikut:

$$
\begin{aligned}
\mathrm{P} 0= & 10 \% \text { silase }+30 \% \text { rumput lapang }+60 \% \\
& \text { konsentrat }
\end{aligned}
$$

\section{Tata laksana penelitian}

Mempersiapkan bahan dan alat setelah itu batang pisang di cacah manual dengan ukuran 3-4 cm sebanyak $30 \%$ dan di campur dengan dedak padi $25 \%$, Pollard $40 \%$ dan tetes tebu (molases) $5 \%$, EM4 1 sebayak \% dan air secukupnya. kemudian semua bahan di masukkan ke dalam (silo) toples kerupuk diameter 30, kemudian dipadatkan untuk meminimlkan udara. Kemudian disimpan ditempat teduh selama 2 minggu (14 hari) dan Selama pembuatan silase dilakukan pengamatan berupa $\mathrm{pH}$ perubahan fisik berupa warna, tekstur bau dan $\mathrm{Ph}$. silase sudah matang jadi silase yang telah jadi akan beraroma harum seperti tape. Kemudian diberikan kepada ternak domba..

\section{Variabel pengamatan}

\section{Kualitas fisik}

Variabel yang diukur adalah warna, tekstur,aroma dan $\mathrm{pH}$ ( Tabel 1.)

Tabel 1. Pengukuran Silase.

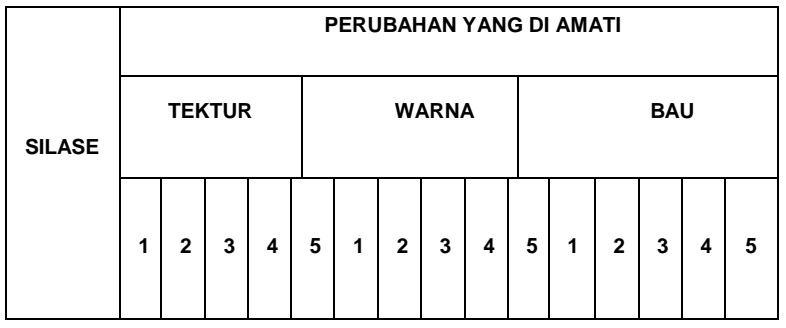

Tekstur 1. Sangat Lembek; 2. Lembek 3. Agak lembek 4. Agak Keras; 5. Keras Warna 1. Hitam; 2. Coklat kehitaman3. Coklat 4. Coklat kehijauan; 5. Coklat kekuningan. Bau 1. Tenggik 2. Tidak asam; 3. Sedikit asam; 4. Asam; 5. Keasaman

\section{Palatabilitas}

Konsumsi Pakan (gram/hari) = pakan yang di berikan - sisa pakan

Konsumsi pakan per minggu $=$

Konsumsi selama pemeliharaan (gram/ekor) Lama Penelitian (minggu)

\section{PEMBAHASAN}

\section{Kualitas Fisik Silase Batang Pisang}

Penilaian uji kualitas fisik silase batang pisang (Musa paradisiaca) yang meliputi tekstur, warna, aroma, dan $\mathrm{pH}$ yang di dapatkan sebagai berkut : 


\section{Tektur Silase}

Tekstur merupakan salah satu indikator penentu kualitas fisik silase batang pisang, semakin lembut dan keras menanndahkan bahwa kualitas silasse yang baaik. Hasil teksstur silase bisa di lihat pada gambar 1.1 sebagai berikut

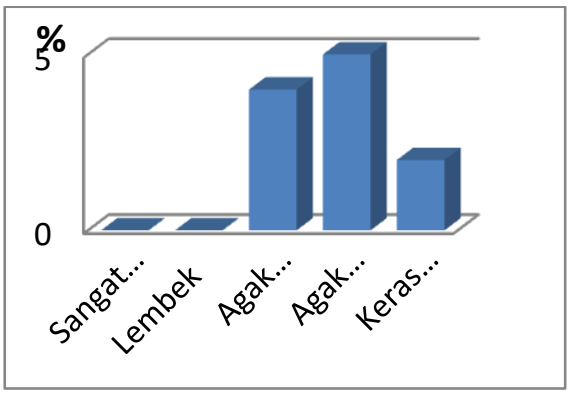

Hasil penelitian ini menunjukan terdapat 3 kriteria yang dipilih responden, yang pertama skor 3 yang berkriteria agak lembek sebanyak 4 orang (\%). Yang ke 2 dengan penilaian agak keras dan lembut dengan skor 4 dipilih oleh 5 orang (\%) .

Skor yang digunakan pada penelitian ini berkisar 1-5 dari kualiatas jelek dengan skor terendah dan skor paling tinggi menandahkan kulitas terbaik, hasil penelitian paling banyak memilih pada skor 4 dengan kriteria agak keras dan lembut. Hal ini sesuai dengan pendapat Macaulay (2004).Yang menjelaskan bahwa tekstur silase dengan kualitas sedang bahan lebih lembut dan mudah dipisahkan dari serta serta di dukung pendapat McEllary (1994) (dimodifikasi) yaitu agak keras dan lembut.

\section{Warna}

Berdasarkan penelitian presentase kriteria warna silase yang dipilih panelis hanya 3 kriteria penilaian. Yang pertama dengan skor 3 terdapat 8 orang (\%). Hanya 1 orang yang memberikan penilaian di skor 4 (\%). Sedangkan skor 3 panelis hanya terdapat 2 orang (\%).Dari penelitian diketahui bahwa mayoritas panelis memilih warna coklat (skor 3) kriteria warna silase yang baik adalah mendekati warna aslinya yaitu warna saat sebelum dibuat menjadi silase. Warna bahan pakan sebelum dibuat berbeda dengan warna aslinya karena dipengaruhi oleh penambahan bahan adiktif.

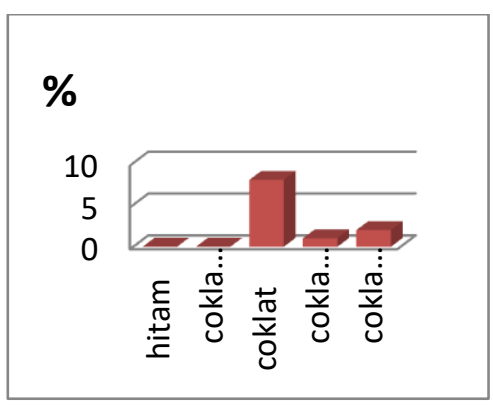

Hal ini sesui dengan pendapat Siregar (1996) bahwa, secara umum silase yang baik mempunyai ciri-ciri yaitu berwarna hijau atau kecoklatan. Sedangkan temuan Hermanto (2011) menyatakan warna silase yang baik adalah coklat terang dan kekuningan. Warna coklat muda di karenakan daun klorofil telah hancur selama proses ensilase,

\section{Aroma silase}

Berdasarkan hasil penelitian diketahui bahwa terdapat 3 kriteria yang dipilih oleh panelis, yang pertama skor 3 yang berkriteria agak lembek dipilih 2 orang (\%). Yang ke 2 dengan penilaian agak keras dan lembut skor 4 yang berjumlah 8 orang ( $8 \%$ ) dan yang ke 3 dengan kriteria keras dan lembut skor 5 terdapat hanya 1 orang (\%), hal ini sesuai dengan pendapat Macaulay (2004) bahwasanya bau silase yang baik adalah asam agak tengik dan bau amoniak sedangkan Menurut McEllary (1994) bau silase yang baik adalah asam

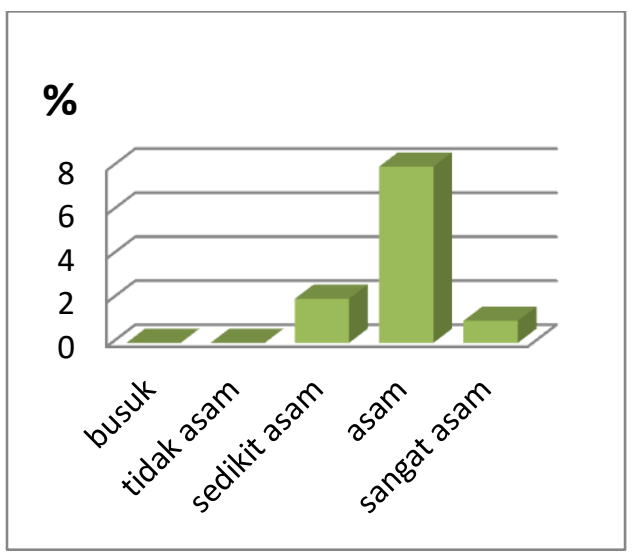


pH

Berdasarkan hasil penelitian uji $\mathrm{pH}$ diketahui apabila $\mathrm{pH}$. Dari $\mathrm{Ph} 4.1$ tersebut di kategorikan bahwa pakan silase batang pisang (musa paradisiaca) memiliki kualitas yang baik sesuai dengan kriteria Sandi et al. (2010) yang menyatakan bahwa kualitas silase dapat digolongkan menjadi empat kategori, yaitu

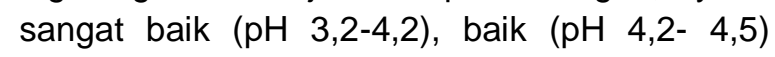
sedang $(\mathrm{pH} 4,5-4,8)$ dan buruk $(\mathrm{pH}>8)$.

\section{Palatabilitas}

\begin{tabular}{|c|c|c|c|c|c|c|c|}
\hline & \multirow{2}{*}{ Kelompok } & \multicolumn{4}{|c|}{ Minggu } & \multirow{2}{*}{ Total } & \multirow{2}{*}{ Rataan } \\
\hline & & I & II & III & IV & & \\
\hline \multirow[t]{2}{*}{ P0 } & Jantan & $1.113,6$ & $1.168,7$ & 1.247 & 1.305 & $4.834,3$ & $1.208,6$ \\
\hline & Betina & $1.325,5$ & $1.332,8$ & $1.429,1$ & $1.419,7$ & $5.506,9$ & $1.376,7$ \\
\hline \multirow[t]{2}{*}{ P1 } & Jantan & 1.160 & $1.186,1$ & 1.247 & 1.305 & $4.898,1$ & $1.224,5$ \\
\hline & Betina & $1,499,3$ & $1.475,91$ & $1.405,3$ & $1.603,4$ & $5.983,91$ & $1.495,9$ \\
\hline \multirow[t]{2}{*}{$\mathrm{P} 2$} & Jantan & $1.409,4$ & $1.408,7$ & 1.624 & $1.663,1$ & $6.105,2$ & $1.526,3$ \\
\hline & Betina & 995,73 & $1.415,2$ & $1.559,1$ & $1.612,14$ & $5.582,17$ & $1.395,5$ \\
\hline \multirow[t]{2}{*}{ P3 } & Jantan & $2.079,3$ & $1.980,63$ & $1.793,1$ & $1.781,6$ & $7.634,63$ & $1.908,6$ \\
\hline & Betina & $1.225,6$ & $1.390,3$ & $1.521,7$ & $1.499,7$ & $5.637,3$ & $1.409,3$ \\
\hline
\end{tabular}

Tabel 5.1 Palatabilitas silase batang pisang

Berdasarkan tabel 5.1 menujukan bahwa $\mathrm{P}_{3}$ memiliki rataaan konsumsi yang paling tinggi di bandingkan dengan perlakuan yang terdapat di $P_{0}, P_{1}$ dan $P_{3}$. Untuk jantan dapat mengkonsumsi $1.908 \mathrm{gr} / \mathrm{ekor} / \mathrm{hari}$ dan betina 1409 gr/ekor/hari. Hal dikarenakan bobot awal domba penelitian pada $\mathrm{P}_{3}$ paling tinggi sehingga jumlah pemberian pakan sesuai dengan berat badan hidup, Menurut Parakkasi (1983) palatabilitas dipengaruhi oleh sifat fisik dan kimia pakan, produksi, berat hidup dan perkembangan saluran pencernaaan.

Pada perlakuan $\mathrm{P}_{2}$, jumlah konsumsi ransum meningkat setiap minggu, hal ini berbeda dengan perlakuan $\mathrm{P}_{0}, \mathrm{P}_{1}$ dan $\mathrm{P}_{3}$ yang jumlah konsumsinya fluktuatif pada (Tabel 4.1). Halini sesuai dengan pendapat Yulianto $d k k$ (2014) bahwa pakan silase sebaiknya di berikan $25-30 \%$ dari total kebutuhan pakan ternak.

\begin{tabular}{|c|c|c|c|c|c|c|}
\hline $\begin{array}{c}\text { Sumber } \\
\text { Keragaman } \\
\text { (SK) }\end{array}$ & $\begin{array}{l}\text { Derajat } \\
\text { Bebas } \\
\text { ( D B ) }\end{array}$ & $\begin{array}{l}\text { Jumlah } \\
\text { Kuadrat } \\
(\mathrm{J} \mathrm{K})\end{array}$ & $\begin{array}{l}\text { Kuadrat } \\
\text { Tengah } \\
(\mathrm{K} \mathrm{T})\end{array}$ & F.hitung & F Tabel & \\
\hline & & & & & $0,05^{*}$ & $0,01^{* *}$ \\
\hline Kelompok & 1 & 16,675 & 16,675 & 269.38 & $10,13^{*}$ & $34,12^{\star \star}$ \\
\hline Perlakuan & 3 & 0,1557 & 0,0519 & 0.838 & 9,28 & 29,46 \\
\hline Galat & 3 & 0,1856 & 0,0619 & & & \\
\hline Total & 7 & 17,0163 & & & & \\
\hline
\end{tabular}

Tabel 5.2 Analisis Ragam Hasil Perhitungan Konsumsi Pakan Silase Batang Pisang (Musa paradisiaca) 
Berdasarkan analisi statistik dalam Tabel 5.2 dapat diketahui bahwa hasil dari analisis ragam palatabilitas konsumsi pakan silase batang pisang (Musa paradisiaca) adalah $(P>0,05)$ berbeda nyata dengan taraf signifikan $5 \%$ maka $\mathrm{H}_{0}$ diterima $\mathrm{H}_{1}$ ditolak, artinya tidak berbeda nyata pengaruh palatabilitas terhadap perbedaan presentase pemberian silase batang pisang (Musa paradisiaca) sehingga rumput bisa diganti dengan silase sebagai pakan ternak domba ekor gemuk.

Untuk pengelompokan yang berdasarkan jenis kelamin menunjukan hasil bahwa palatabilitas jantan lebih besar dari pada betina pada taraf signifikan $5 \%(P<0,05)$ menghasilkan berbeda nyata dan taraf signifikan $1 \%(P<0,01)$ menghasikan berbeda nyata.

\section{KESIMPULAN}

1. Kualitas fisik (tekstur, warna, aroma dan $\mathrm{pH}$ ) silase batang pisang (Musa paradisiaca) sangat baik yang di tujukan oleh sifat fisik silase.

2. Tidak terdapat pengaruh perbedaan presentasi pemberian silase batang pisang (Musa paradisiaca) terhadap perlakuan dan pengelompokan berdasarkan jenis kelamin sangat berbeda nyata pada palatabilitas ternak domba ekor gemuk.

\section{DAFTAR PUSTAKA}

Hasrida.2011. "Pengaruh Dosis Urea dalam Amoniasi Batang Pisang terhadap Degradasi Bahan Kering, Bahan Orgamnik, dan Protein Kasar secara IN_VITRO"(SkripsiS-1 Jurusan Nutrisi dan MakananTernak, Fakultas Peternakan). Padang: Universitas Andalas.

Hermanto, 2011. Sekilas agribisnis peternakan indonesia. Konsep pengembangan peternakan, menuju perbaikan ekonomi rakyat serta meningkatkan gizi generasi mendatang

Profil dan Potensi Kabupaten Lamongan, 2017
Macaulay, A. 2004. Evaluanting silage quality.

McEllhlary, R. R. 1994. Feed Manufacuring Technology IV. Am. Feed Industry Assoc. Inc.Aruington.

Parakasi, A. 1983. IImu Gizi dan Makanan Ternak Monogastrik. Angkasa, Bandung.

Sandi, S., E. B. Laconi, A. Sudarman, K. G. Wirawan dan D. Mangundjaja. 2010 kualitas nutrisi silase berbahan baku singkong yang diberi enzim cairan rumen sapi dan Leuconotoc mesenteroides. Media Peternakan. 33: 25-30.

Siregar, M.E. 1996. Pengawetan Pakan Ternak. PenebarS wadaya. Jakarta.

Yulianto, purnawan dan cahyono saparinto. 2014. Beternak sapi limousin. Penebar swadaya. Semarang. 